Surgical Note

\title{
Anterior Maxillary Distraction - a Boon to Treat Cleft Maxillary Hypoplasia
}

\author{
Sunil Richardson 1, *, Dhivakar Selvaraj ${ }^{2}$, Shreya Krishna ${ }^{3}$ \\ ${ }^{1}$ Richardson's Dental and Craniofacial Hospital, Nagercoil, Tamil Nadu, India (Director) \\ 2 Department of Orthodontics, Rajas Dental College and Hospital, Thirunelveli, Tamilnadu, India (Prof) \\ ${ }^{3}$ Richardson's Dental and Craniofacial Hospital, Nagercoil, Tamil Nadu, India (Surgical Fellow)
}

\section{ABOUT ARTICLE}

Article history:

Paper received 10 June 2017

Accepted 11 June 2017

Available online 30 June 2017

Keywords:

Anterior maxillary distraction

Cleft maxillary hypoplasia

Le Fort I osteotomy

Le Fort I distraction

Velopharyngeal closure

Maxillary osteotomy

Tooth-borne screw appliance

Implants-supported fixed partial

denture (FPD)

\begin{abstract}
A B S T R A C T
We describe our experience of using anterior maxillary distraction for the correction of cleft related maxillary hypoplasia. Clear historical overview and meticulous description of the surgical technique are given. The technique is described step-by-step from the type of incision to the prosthetic rehabilitation. An advantage of anterior maxillary distraction over the other conventional techniques is reasoned. The paper is illustrated both the view of intra-oral tooth-borne screw appliance and four representative cases. This technique provides excellent well-predicted result and can be widely recommended in anterior maxillary distraction.

() Diagnostics and Treatment of Oral and Maxillofacial Pathology. Published by OMF Publishing, LLC. All rights reserved.
\end{abstract}

\section{Introduction}

Age-old techniques like Le Fort I osteotomy and Le Fort I distraction have been used for correction of cleft related maxillary hypoplasia [1]. In 2003, Dolanmaz first used the anterior segmental maxillary distraction technique [2]. Since then it has become a very useful technique for correction of cleft related maxillary hypoplasia. The greatest advantage of anterior maxillary distraction over the other aforementioned conventional techniques is that since only the anterior portion of the maxilla is being moved forward, there is no worsening effect on velopharyngeal closure [3, 4].

\section{Surgical and Prosthetic Techniques}

The appliance (Fig 1) can be placed intra-operatively as advocated by Gunaseelan or it can be placed prior to operation as practiced by the author. This prevents cement failure. The procedure takes place under general anesthesia with oral endotracheal intubation. A maxillary vestibular

\footnotetext{
* Corresponding author. Richardson's Dental and Craniofacial Hospital, \# 71, Trivandrum Highway, Chunkan,620003 Nagercoil, Tamil Nadu, India Tel.: +919443182860. /+96890183713 E-mail address: drsunilrichardson@hotmail.com (S. Richardson) Instagram: @drsunilrichardson
}

incision is made from first molar to another molar. The mucoperiosteum is reflected to expose the maxillary bone up to the infraorbital foramen. A buccal linear osteotomy cut is made on both sides at a similar level with a 701 bur under copious irrigation above the level of the root apices from the pyriform rim to the predetermined distraction site between the premolars and molars parallel to the occlusal plane. Lateral nasal osteotomes are used to cut the lateral nasal wall from the pyriform rim at the same level of the buccal cut on both sides. Care is taken to protect the nasal mucosa. The nasal septum is then transected at its base just beyond the distraction site using a guarded septal

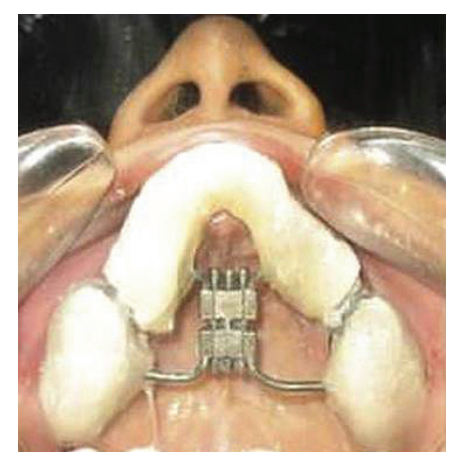

FIGURE 1. Intra-oral tooth-borne screw appliance. 

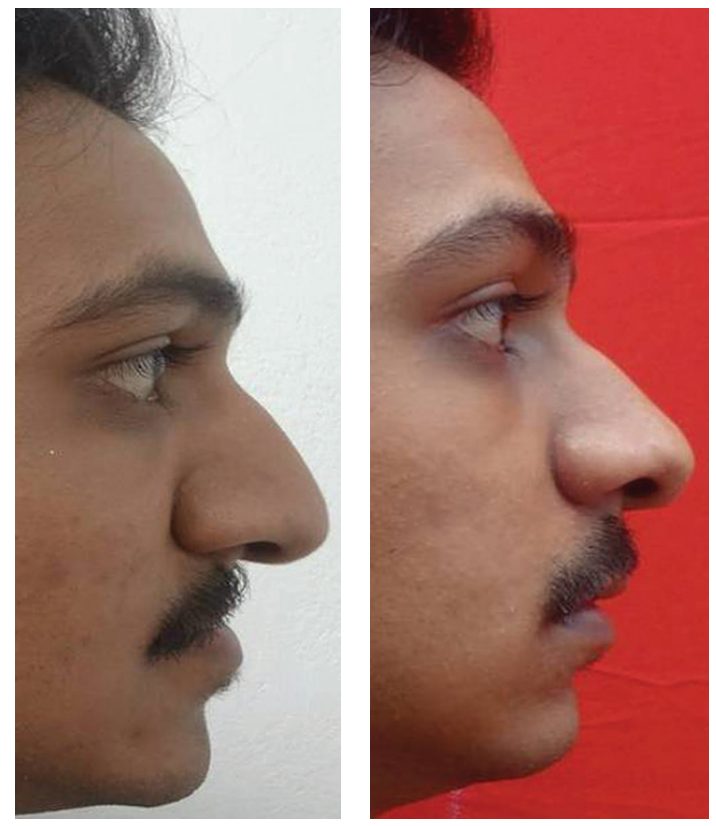

CASE 1. Result after anterior maxillary distraction. Photographs before $(\mathbf{A})$ and after $(\mathbf{B})$ treatment.

osteotome. Vertical interdental cuts are made between the second premolar and first molar through the buccal cortex using a bur. These are then deepened using spatula osteotomes. This is followed by palatal osteotomy using a curved osteotome with very gentle force because using tactile sensation for guidance. The palatal bone is not cut completely to avoid damage to the periosteum. Luxation on both sides is performed using gentle force to fracture the anterior maxilla. The completion of the osteotomy cut is confirmed by activation of the distractor screw intraoperatively and symmetrical movement on both sides was confirmed. Closure of the vestibular incision was then performed using a 3-0 Vicryl suture. Activation of the screw starts typically on the fifth postoperative day and at the rate of four turns twice a day. This advances the maxilla by $0.72 \mathrm{~cm}$ per day.

After completion of distraction, the maxilla is left for consolidation for 12-14 weeks. Thereafter the appliance is removed and prosthetic rehabilitation for the gap created is done by fixed partial denture (FPD)/dental implants

\section{Conclusions}

This technique improves dental arch crowding, advances the maxilla and improves the profile of the patient and is also better for the speech of the patient [5].
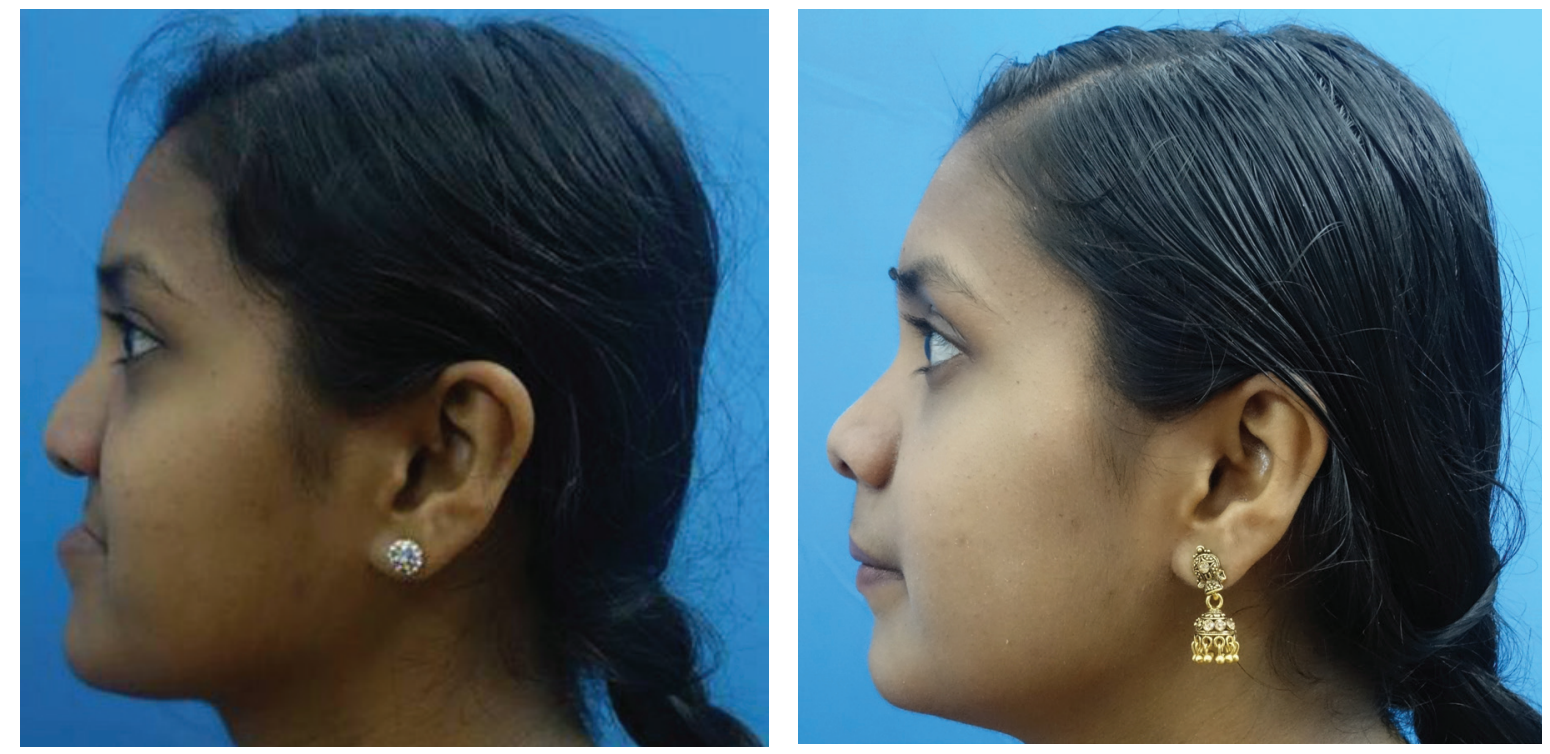

CASE 2. Patient showing good results after anterior maxillary distraction. Photographs before $(\mathbf{A})$ and after $(\mathbf{B})$ treatment. 

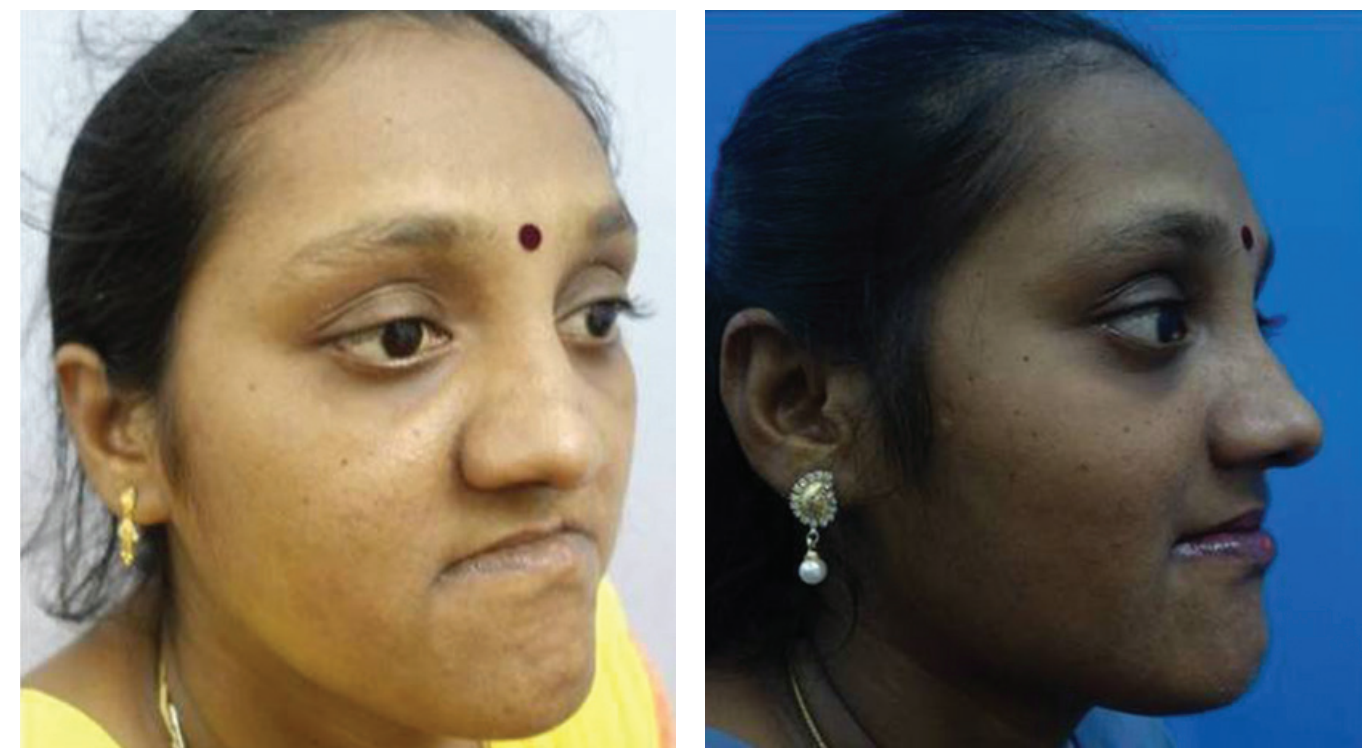

CASE 3. Excellent improvement in facial profile. Clinical photographs before (A) and after (B) treatment.
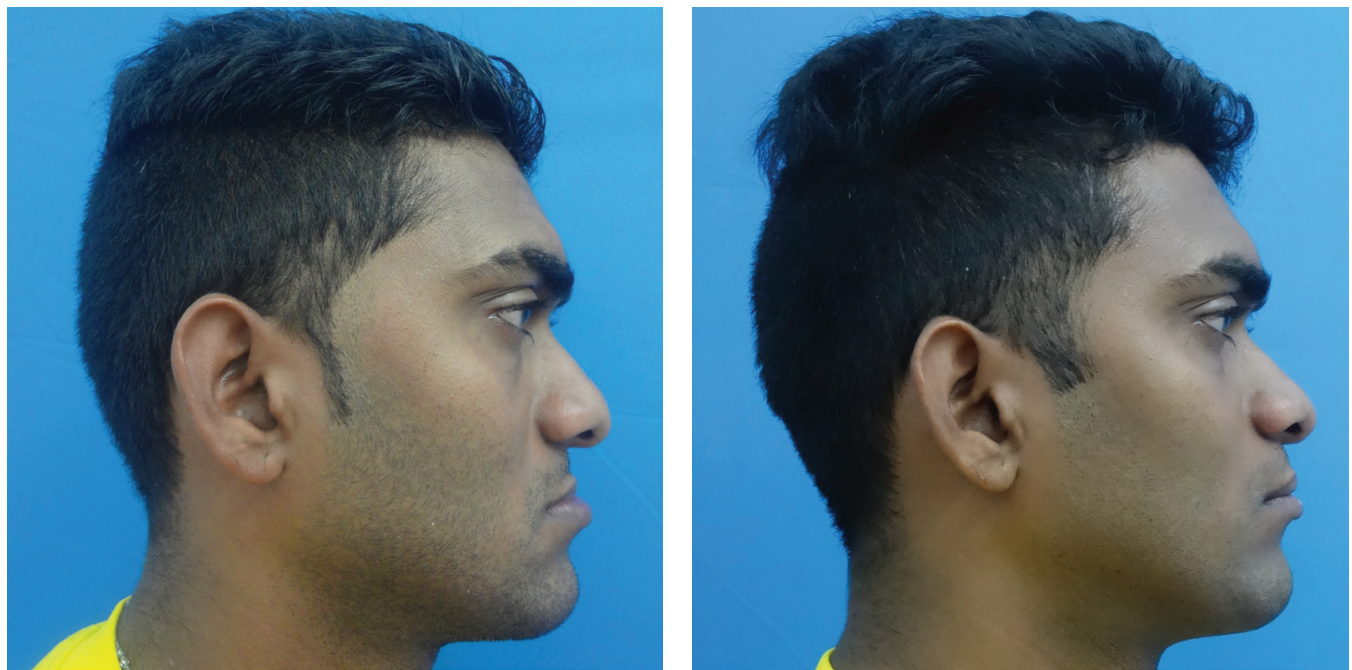

CASE 4. Improvement in facial profile. Clinical photographs before (A) and after (B) treatment.

Funding

None.

\section{Conflict of Interests}

The authors declare no conflict of interest.

\section{Role of Author and Co-authors}

Sunil Richardson (concept of the paper and writing). Dhivakar Selvaraj (material collection and writing). Shreya Krishna (editing).

\section{Ethical Approval}

Approval was obtained from the Medical Ethics Committee of the Rajas Dental College and Hospital.

\section{Patient Consent}

Written patient consent was obtained to publish the clinical photographs.

\section{References}

1. Wang XX, Wang X, Li ZL, Yi B, Liang C, Jia YL, Zou BS. Anterior maxillary segmental distraction for correction of maxillary hypoplasia and dental crowding in cleft palate patients: a preliminary report. Int J Oral Maxillofac Surg 2009;38:1237. http://dx.doi. org/10.1016/j.ijom.2009.06.028.

2. Dolanmaz D, Karaman AI, Ozyesil AG. Maxillary anterior segmental advancement by using distraction osteogenesis: a case report. Angle Orthodon 2003;73:201-5. http://dx.doi.org/10.1043/00033219(2003)73<201:MASABU>2.0.CO;2. 
3. Richardson S, Agni NA, Selvaraj D. Anterior maxillary distraction using a tooth-borne device for hypoplastic cleft maxillas - a pilot study. J Oral Maxillofac Surg 2011;69:e542-e548. http://dx.doi.org/10.1016/j. joms.2011.08.013.

4. Richardson S, Seelan NS, Selvaraj D, Khandeparker RV, Gnanamony S. Perceptual speech assessment after anterior maxillary distraction in patients with cleft maxillary hypoplasia. J Oral Maxillofac Surg 2016;74:1239.e1-1239.e9. http://dx.doi.org/10.1016/j. joms.2016.02.006.

5. Richardson S, Selvaraj D, Khandeparker R, Seelan NS, Richardson S. Tooth-borne anterior maxillary distraction for cleft maxillary hypoplasia: our experience with 147 patients. J Oral Maxillofac Surg 2016;74:2504.e1-2504.e14. http://dx.doi. org/10.1016/j.joms.2016.08.036.

Richardson S, Selvaraj D, Krishna S.

Anterior maxillary distraction - a boon to treat cleft maxillary nypoplasia.

J Diagn Treat Oral Maxillofac Pathol 2017;1:65-8.

http://dx.doi.org/10.23999/j.dtomp.2017.2.3.

Хірургічний запис

\section{Дистракція переднього сегменту верхньої щелепи - перевага в усуненні недорозвитку верхньої щелепи, спричиненого їі розщілиною}

Суніл Річардсон'1, Дхивакар Селварай², Шрея Кришна

${ }^{1}$ Стоматологічний та краніофааціальний госпіталь імені Річардсона, Нагеркойл, Таміл Наду, Індія

2 Відеділення ортодонтії, коледж та лікарня Раджас, Тирунелвелі, Тамілнаду, Індія (просресор) Стоматологічний та краніосаашіальний госпіталь імені Річардсона, Нагеркойл, Таміл Наду, Індія (хірургічний працівник після резидентури)

\section{П Р О С ТА Т Т Ю}

Історія рукопису:

Отриманий: 10 червня 2017 року Прийнятий: 11 червня 2017 року Онлайн з: 30 червня 2017 року

Ключові слова:

Дистракція переднього сегмент верхньої щелепи

Недоразвиток верхньої щелепи викликаний іiї щілиною

Остеотомія по Ле Фор I

Дистракція по Ле Фор I

Піднебінно-глоткове з'єднання

Гвитовий апарат з опорою на зуби

Частковий фіксований протез

3 опорою на імплантати

\section{P E 3 Ю M E}

Ми описуємо наш досвід використання дистракцій переднього сегмента верхньої щелепи для корекції недорозвитку верхньої щелепи, спричиненим ії розщілиною. Наведено чіткий історичний огляд і докладний опис хірургічної техніки. Методика описується покроково від типу розрізу до ортопедичної реабілітаціі. Обгрунтована перевага дистракції переднього сегмента верхньої щелепи порівняно з іншими класичними методами. Стаття проілюстрована гвинтовим апаратом з опорою на зуби, який використовується в цій методиці, так і на чотири клінічні випадки. Ця методика забезпечує відмінний, добре прогнозований результат і може бути широко рекомендована для дистракції переднього сегмента верхньої щелепи.

\section{Хирургическая записка}

Дистракция переднего сегмента верхней челюсти преимущество в коррекции недоразвития верхней челюсти вызванного её расщелиной

Сунил Ричардсон ${ }^{1}$, Дхивакар Селварай², Шрея Кришна

${ }^{1}$ Стоматологический и краниофаациальный госпиталь имени Ричардсона, Нагеркойл, Тамил Наду, Индия (директор)

2 Отделение ортодонтии, Колледж и больница Раджас, Тирунелеели, Тамилнаду, Индия (профессор) Стоматологический и краниофрациальный госпиталь имени Ричардсона, Нагеркойл, Тамил Наду, Индия (хирургический сотрудник после резидентуры)

\section{O CTATbE}

История рукописи:

Получена: 10 июня 2017 года Принята: 11 июня 2017 года Онлайн с: 30 июня 2017 года

Ключевые слова:

Дистракция переднего сегмента верхней челюсти

Недоразвитие верхней челюсти вызванное ее расщелиной

Остеотомия по Ле Фор I Дистракция по Ле Фор I

Небно-глоточное смыкание Винтовый аппарат с опорой на зубы

Частичный фиксированный протез с опорой на имплантаты

\section{P E 3 Ю M E}

Мы описываем наш опыт использования дистракций переднего сегмента верхней челюсти для коррекции недоразвития верхней челюсти, которое вызванное ее расщелиной. Приведен четкий исторический обзор и описание хирургической техники. Методика описывается пошагово от типа разреза к ортопедической реабилитации. Обосновано преимущество дистракции переднего сегмента верхней челюсти по сравнению с другими классическими методами. Статья проиллюстрирована как винтовым аппаратом с опорой на зубы, что используется в этой методике так и на четырьмя клиническими случаями. Эта методика обеспечивает отличный, хорошо прогнозируемый результат и может быть широко рекомендована для дистракции переднего сегмента верхней челюсти. 